\title{
Climate change impact, adaptation and associated costs for coastal risks in France
}

\author{
Gonéri Le Cozannet, BRGM, g.lecozannet@brgm.fr \\ Nicole Lenôtre, BRGM, n.lenotre@brgm.fr \\ Marissa Yates Michelin, BRGM, m.yates@brgm.fr \\ Philippe Nacass, Météo-France, philippe.nacass@meteo.fr \\ Bastien Colas, MEEDDM/SGDD/SoES, sebastien.colas@developpement-durable.gouv.fr \\ Céline Perherin, Cetmef, Celine.Perherin@developpement-durable.gouv.fr \\ Cédric Peinturier, MEEDDM/CGDD/SEEl, cedric.peinturier@developpement-durable.gouv.fr \\ Cyril Vanroye, DREAL/LR, Cyril.Vanroye@developpement-durable.gouv.fr \\ Chadi Hajji, MRN, chadi.hajii@mrn.gpsa.fr \\ Bernard Poupat, bernard.poupat@developpement-durable.gouv.fr
}

Catherine Azzam, MEEDDM/DGPR/SRNH/BRM, Catherine.Azzam@developpement-durable.gouv.fr

Jérôme Chemitte, MRN, jerome.chemitte@mrn.gpsa.fr

Frédéric Pons, CETE Méditerranée, Frederic.Pons@developpement-durable.gouv.fr

\begin{abstract}
As part of the French climate plan, an inter-ministerial working group called "climate change impacts, adaptations, and associated costs in France" was created to evaluate potential damages caused by climate change and to identify possible mitigation measures. Seven thematic committees were organised, including the "natural risks, insurance and adaptation to climate change" committee, within which the coastal risks working group focused on the impacts of erosion and coastal inundation. This paper presents the methodology, results, and recommendation of this working group.
\end{abstract}

A risk estimation methodology - where risk is considered as a combination of hazard and the vulnerability of the exposed assets - was developed at a regional scale for LanguedocRoussillon in 2100. Sea level rise and hazard evolution scenarios were used to estimate the costs of damages to exposed assets. The results serve as a rough estimate of the direct and indirect tangible costs potentially induced by coastal erosion and inundation in the $21^{\text {st }}$ century. This paper discusses the results, addressing the uncertainties in each step of the assessment, specifically identifying the factors that were not taken into account and the limitations of the data sets. Finally, recommendations of adaptation measures, spatial planning, and short-term risk management were produced.

Keywords: erosion, inundation, risk analysis, Languedoc-Roussillon

\section{Introduction}

It is generally accepted that climate change will exacerbate existing coastal hazards of erosion and inundation in the $21^{\text {st }}$ century (Nicholls et al. 2007). In France, $25 \%$ of the shoreline is retreating (Eurosion, 2004), and the vulnerability of low-lying coastal areas to 
flooding has been highlighted by the impacts of several storms: Lothar in 1999 and Xynthia in 2010 (Atlantic coast), and the 1982, 1997, and 2003 storms in Languedoc-Roussillon.

Methods for evaluating and addressing climate change impacts have been developed during the last 20 years. Following the International Panel on Climate Change (IPCC) recommendations in 1991, a "Common Methodology" was developed, focusing on vulnerability assessment and adaptation strategy development (Nicholls et al. 1995). More recently, the DIVA (Dynamic Interactive Vulnerability Assessment) tool was developed to quantify the potential impacts of sea level rise on a range of coastal vulnerability indicators (McFadden et al. 2007). However, in France the quality of available data is a major limitation in the application of this approach (Romieu and Vinchon. 2009).

An inter-ministerial working group called "climate change impacts, adaptations and associated costs in France" was created to evaluate potential damages due to climate change and possible mitigation measures. The "natural risks, insurance and adaptation to climate change" (RNACC) committee formed a working group charged with evaluating coastal risks and the impacts of erosion and inundation.

The working group selected the Languedoc Roussillon region as a study site due to the exposure of many low-lying coastal zones to ongoing coastal erosion and persistent inundation during storm events. Languedoc-Roussillon is situated on the Mediterranean coast of France, with $215 \mathrm{~km}$ of shoreline between the border of Spain and the Rhône delta. Implemented adaptation measures include beach nourishments, the placement of coastal defence structures, and the relocation of a highway and other exposed assets.

This paper presents the hazard evaluation methodology, results, and recommendations for Languedoc-Roussillon in 2100 [see Le Cozannet et al. (2009) for the full report (in French)].

\section{Data and methodology}

\subsection{Evaluation of the potential climate change impacts}

Climate change aggravates two existing coastal hazards: erosion and temporary inundation caused by storm waves; and it creates a new hazard: permanent inundation due to sea level rise. This study evaluates the impacts of these hazards using a classical risk estimation methodology, where risk is considered as a combination of the hazard and the vulnerability of exposed elements. The methodology is outlined in Fig 1.

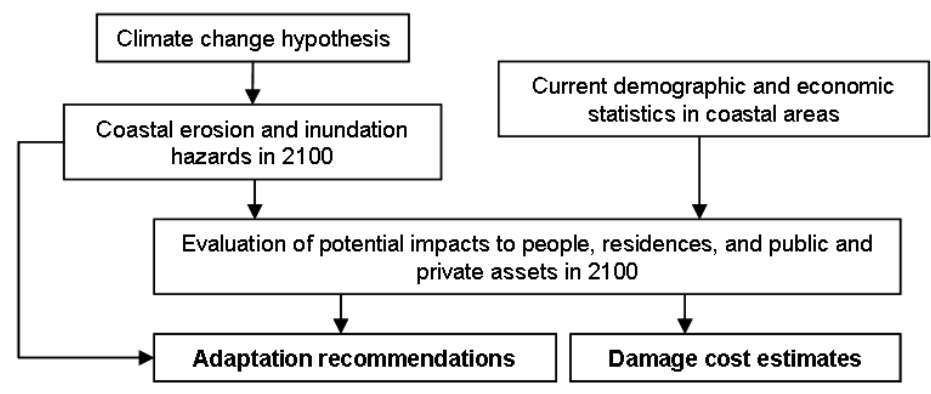

Fig. 1 : Methodology applied within the RNACC Coastal Risks study

The selected climate change hypothesis leads to changes in coastal flooding and erosion hazards, and the impacts are evaluated in terms of the exposure of people and residences, and the damage costs. The potential impacts are estimated from changes in coastal hazards, and recommendations are made for adaptation measures.

One of the limiting hypothesis is that the current demographic statistics are used to evaluate the potential impacts in 2100 . Although current demographic trends show increases, present- 
day demographic statistics are used in this study due to the uncertainties associated with estimating future population and economic growth.

\subsection{Climate change hypothesis}

Nicholls et al. (2007) emphasised the importance of sea level rise as a primary factor influencing coastal change. Following the scenarios of global greenhouse house emissions detailed by the IPCC (2007), expected rates of global sea level rise in coupled oceanatmosphere models are 30 to $60 \mathrm{~cm}$ (Meehl et al., 2007). However, recent studies have suggested higher values of $1 \mathrm{~m}$ or more (Hansen, 2007; Rahmstorf, 2007; Grinsted et al., 2009), due to uncertainties in modelling polar ice sheet melting. In the Mediterranean Sea, the estimation of sea level rise is even more complex due to the narrow connection with the Atlantic Ocean. Tsimplis et al. (2008) created a model of the steric effect on the sea level rise (due to temperature and salinity changes only), which predicted no sea level rise along the French Mediterranean coast, but the authors warned of the need to validate the model results. Observations of recent relative sea level rise (relative to the land) from tide gauges show rates of 1 to $3 \mathrm{~mm}$ /year (EUROSION, 2004; Ullman et al., 2007; MICORE, 2009). Due to the uncertainties in estimating sea level rise in the Mediterranean, the scenario of $1 \mathrm{~m}$ of sea level rise by 2100 was chosen for this study, consistent with the values proposed by Rahmstorf (2007) and Grinsted et al. (2009).

Other potential impacts of climate change could include changes in storm regimes, storm surges, the coastal wave climate, and precipitation patterns. Regional climate models have not shown significant changes in Languedoc-Roussillon (Déqué et al., 2003; Ullman, 2008; Lionello et al., 2008; MICORE, 2009), except for a potential decrease in total precipitation, while the number of heavy rain days (more than $10 \mathrm{~mm}$ ) may increase (IMFREX, 2002). However, the impacts are unable to be quantified and are not taken into account in this study. Therefore, this study estimates that the primary influence of climate change in Languedoc-Roussillon will be caused by a 1 meter increase of the sea level by 2100 .

\subsection{Hazard evolution}

Garcin et al. (2008) analyzed the characteristics of potential hazard changes due to sea level rise (Fig. 2). In Languedoc-Roussillon, erosion is dominated by the long term evolution of sandy beaches and lidos, which are sandy barriers located between the sea and inland lagoons. With continued sea level rise and a limited sediment supply, Paskoff (2001) estimated that lidos would evolve similar to barrier islands, by retreating landward, forming additional openings, and reducing in total surface. In this study, a buffer zone of $500 \mathrm{~m}$ is chosen to estimate the possible extent of erosion by the year 2100 . This arbitrary value is a compromise between the uncertainties in estimating erosion for various morphologies and the precision of the elevation data used in the study.

Coastal inundation has two components (see Fig. 2) that act on different timescales due to different physical processes. Sea level rise creates the new hazard of permanent inundation, which occurs over long time scales and is considered irreversible. With an estimated sea level rise of $1 \mathrm{~m}$, all coastal zones at less than $+1 \mathrm{~m}$ elevation will be considered inundated in the year 2100. In addition to permanent inundation, temporary inundation during storms (caused by storm surges and waves) occurs over the timescale of a storm (hours to days) and is estimated as an extreme water level of $+2 \mathrm{~m}$ (including the effects of wind, atmospheric pressure, and wave setup) for a storm with a 100-year return period (see Fig. 3). 


\begin{tabular}{|l|l|l|l|l|l|}
\hline \multicolumn{1}{|c|}{ Hazard } & $\begin{array}{c}\text { Effect of climate } \\
\text { change }\end{array}$ & \multicolumn{1}{|c|}{ Type } & \multicolumn{1}{c|}{ Timescale } & \multicolumn{1}{c|}{$\begin{array}{c}\text { Reversibility of } \\
\text { effects }\end{array}$} & Proposed estimation of the impact zone \\
\hline Erosion & aggravation & continuous & $\begin{array}{l}\text { intra-annual to } \\
\text { multiannual }\end{array}$ & irreversible & $\begin{array}{l}\text { a buffer zone of } 500 \mathrm{~m} \text { inland of erodible } \\
\text { coastal zones }\end{array}$ \\
\hline $\begin{array}{l}\text { Permanent } \\
\text { submersion }\end{array}$ & $\begin{array}{l}\text { creation of a new } \\
\text { hazard }\end{array}$ & continuous & $\begin{array}{l}\text { multiannual to } \\
\text { decadal }\end{array}$ & irreversible & the zone from $0-+1 \mathrm{~m}$ elevation \\
\hline $\begin{array}{l}\text { Temporary } \\
\text { submersion }\end{array}$ & aggravation & discontinuous & $\begin{array}{l}\text { a few hours to a } \\
\text { few days }\end{array}$ & reversible & the zone between $+1-3 \mathrm{~m}$ elevation, \\
\hline
\end{tabular}

Fig. 2 : Characteristics of the considered hazards and the proposed estimation of the zone exposed to these hazards, applied at the regional scale for this project (adapted from Garcin et al. 2008).

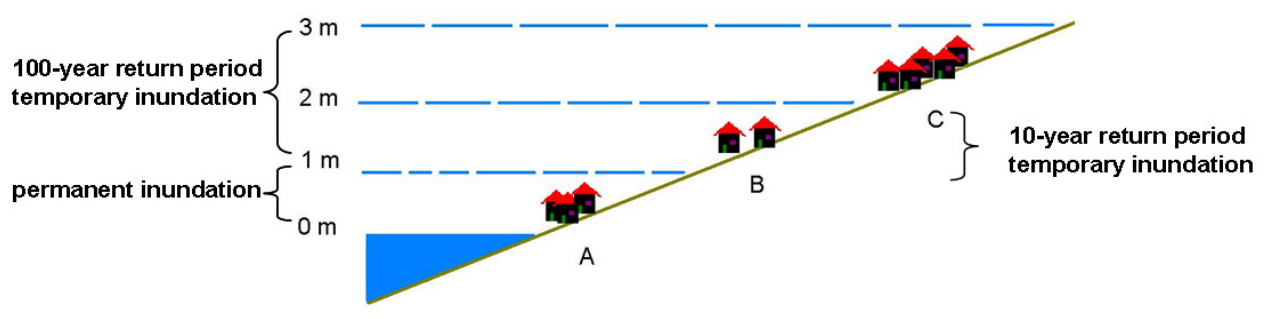

Fig. 3: Defined inundation hazard zones in 2100

\subsection{Exposure of people and residences to coastal hazards}

To assess the evolution of the social and economic impacts of coastal inundation in France, population and residence density models are overlaid with the estimates of eroded and inundated areas to calculate exposure (using a linear model). It is important to note that extreme events can cause human life loss, but slow erosion processes usually cause the relocation of habitants before the residence is lost. Therefore, the number of people exposed to erosion in this study corresponds to an estimation of the number of people who will be expected to lose their residences by 2100 and not an estimation of life loss.

\subsection{Methodology for cost assessment}

In this study, the expected cost of damages is the sum of the values of expected losses, and not the expected macroeconomic cost of disasters, which Hallegatte and Ghil (2008) showed interacting with endogenous economic cycles. Erosion and inundation hazards cause different types of damage (see Fig. 4), and the estimation of intangible damages, as well as tangible but indirect damages, remains ongoing research. This study estimates the cost of potential direct and tangible damages to assets that can be ascribed to coastal hazards due to climate change.

The damages caused by a natural disaster are considerable, but the cost is often difficult to evaluate for several reasons: the cost of damages due to marine inundations are almost always merged with those of continental flooding in public statistics, but also the observed costs are poorly published. In this study, the cost analysis was based on some rare existing statistics of marine and fluvial flooding insured damages but also on the mean value of houses in the considered area.

The value found was used as a proxy to estimate expected tangible costs due to sea level rise in Languedoc-Roussillon. In general, it is estimated that insured damages represent $50 \%$ of the total direct economic losses in developed countries, and indirect economic losses can equal that of direct economic losses. Therefore, a rough approximate of the total cost of the tangible damages could be four times the cost of the damages to insured assets. The cost of intangible losses could not be estimated. 


\begin{tabular}{|c|l|l|}
\hline Examples of damages & \multicolumn{1}{|c|}{ Tangible } & \multicolumn{1}{c|}{ Intangible } \\
\hline Direct & $\begin{array}{l}\text { Destruction of an economic asset } \\
\text { (e.g.. buildings, public transportation or communication } \\
\text { infrastructure, etc.) }\end{array}$ & Loss of human life, or loss of a natural space \\
\hline Indirect & $\begin{array}{l}\text { Loss of use } \\
\text { (e.g. losses due to non-use of property destroyed or } \\
\text { damaged by a catastrophe) }\end{array}$ & $\begin{array}{l}\text { Increase in the vulnerability of the population } \\
\text { affected by a crisis }\end{array}$ \\
\hline
\end{tabular}

Fig. 4: Damage categories and examples. In this study, only the direct, tangible damages can be analyzed, and the value of indirect, tangible losses is estimated.

\subsection{Limitations}

Each step of the process introduces certain errors in the final estimation of costs, and the largest uncertainties were identified as:

- The hypothesis of $1 \mathrm{~m}$ of sea level rise in 2100 , which affects the size of the inundated zone.

- The estimation of the spatial extent of the erosion hazard, which is not currently known due to the level of knowledge of morphodynamics processes at long time scales, and prevents the validation of the best method of estimation.

- The estimation of the spatial extent of all hazards depends on the resolution of the elevation data ( $1 \mathrm{~m}$ vertical) and on the grid size (50 m horizontal), which is known to induce large errors due to the lack of representation of natural barriers like dunes.

- The calculation of the 100-year return storm event, used for the estimation of the extreme water level occurring causing temporary inundation, which was estimated as $2 \mathrm{~m}$ and not calculated with a statistical extreme value analysis.

- The hypothesis of non evolution of stake at risks, which contradicts the observations and the published projections.

- The method of estimating the costs associated with damages was severely limited by a lack of data, and the estimates should be considered as a preliminary analysis.

Therefore, the uncertainties concerning the estimation of costs are rather large and limit the robustness of these results, encouraging future studies.

\section{Results}

\subsection{Exposure}

Keeping in mind the limitations described above, the impact of climate change on the population and residences of the Languedoc-Roussillon region is expected to be:

- the displacement, between 2000 and 2100, of 80,000 people whose residences may be affected by irreversible erosion or permanent inundation

- the destruction, between 2000 and 2100, of 140,000 residences affected by irreversible erosion of permanent inundation

- the exposure of people and residences to higher marine inundation hazard as well as the extension of the maximum extent of this hazard.

However, the hypothesis of constant stakes induces difficulties as the stakes are often located near to the shoreline. The final estimates of people potentially affected by temporary inundation hazard by 2100 lies between 40,000 and 80,000 (between 60,000 and 140,000 residences).

\subsection{Costs}

The costs obtained using the methodology proposed in 2.5 are summarized in table 5 . These costs do not take into account actualization. They must be used cautiously, reminding 
limitations mentioned in 2.6. However, they highlight that the costs induced by erosion might overthrown those of temporary inundation during the $\mathrm{XXI}^{\text {th }}$ century.

\begin{tabular}{|c|c|c|c|}
\hline $\begin{array}{l}\text { Estimations of annual and cumulative costs } \\
\text { of coastal risks caused by climate change }\end{array}$ & $\begin{array}{l}\text { Cost of potential damages to } \\
\text { residences }\end{array}$ & $\begin{array}{l}\text { Cost of direct, tangible } \\
\text { damages (estimate) }\end{array}$ & $\begin{array}{l}\text { Cost of direct and indirect, } \\
\text { tangible damages (estimate) }\end{array}$ \\
\hline $\begin{array}{l}\text { Coastal erosion and permanent inundation } \\
\text { (only destroyed buildings) }\end{array}$ & $\begin{array}{l}150 \text { Million } € / \text { year } \\
\text { Or } 15 \text { Billion } € \text { by } 2100\end{array}$ & $\begin{array}{l}300 \text { Million } € / \text { year } \\
\text { Or } 30 \text { Billion } € \text { by } 2100\end{array}$ & $\begin{array}{l}600 \text { Million } € / \text { year } \\
\text { Or } 60 \text { Billion } € 2100\end{array}$ \\
\hline $\begin{array}{l}\text { Coastal erosion and permanent inundation } \\
\text { (buildings and land loss) }\end{array}$ & $\begin{array}{l}350 \text { Million } € \text { / year } \\
\text { Or } 35 \text { Billion } € 2100\end{array}$ & $\begin{array}{l}700 \text { Million } € / \text { year } \\
\text { Or } 70 \text { Billion } € \text { by } 2100\end{array}$ & $\begin{array}{l}1400 \text { Million } € / \text { year } \\
\text { Or } 140 \text { Billion } € 2100\end{array}$ \\
\hline Temporary inundation & $\begin{array}{l}15 \text { Million } € \text { / year } \\
\text { Or } 1.5 \text { Billion } € \text { by } 2100\end{array}$ & $\begin{array}{l}30 \text { Million } € \text { / year } \\
\text { Or } 3 \text { Billion } € \text { by } 2100\end{array}$ & $\begin{array}{l}60 \text { Million } € \text { / year } \\
\text { Or } 6 \text { Billion } € \text { by } 2100\end{array}$ \\
\hline
\end{tabular}

Table 5: Estimations of the annual and cumulative costs of coastal risks due to climate change between 2000 and 2100 for the Languedoc-Roussillon region.

\section{Discussion}

\subsection{Relevance of results}

One can notice that there are more residences than people in the considered area, which is a common characteristic of touristic areas. In this study, the ageing of the residences was not taken into account, while this should account for huge investments in the next century. However, the estimate fits rather well with one of the rare available observations in this area: the storm of December 16, 1997, which impacted the Languedoc-Roussillon region, with wave heights near the 50-year return value and water levels near the 20-year return value (IMPLIT, 2007), caused 37 million Euros of damages (source: Caisse Centrale de Réassurance). For comparison, this value is approximately the order of magnitude of the expected value of annual damages until 2100 . This compares the cost of a single event to all costs integrated during a year, but allows a scaling of the magnitude of expected damages.

\subsection{Proposed adaptation measures}

The Languedoc-Roussillon region faces large economic and social consequences if no adaptation measures are adopted to mitigate coastal erosion and inundation hazards. At a national scale in France, ONERC proposes that the first step in mitigation is to enhance knowledge (2007), and this working group's specific recommendations include regular data acquisition at a variety of representative study sites to analyze and model better extreme events and long-term coastal evolution, and the acquisition of high resolution topographic and bathymetric data spanning the coast but also the collection and coordination of local, regional, and national coastal data sets (natural phenomena, hazard estimation, vulnerability, asset exposure, damages, costs, etc.).

The second crucial step is the communication of information to clarify the perception of risk. Risk prevention is often set in place following an extreme event, instead of as a preventative step, and when preventative plans are created, prevention measures are often poorly applied when the risk is not perceived. Therefore, the planning recommendations are to reinforce the application of existing regulations, and to take into account coastal risks due to climate change in local, regional, and national level strategic plans and to take into account future climate change in the management of coastal sediment supplies, for example with the acquisition of land by the Conservatoire du Littoral.

In addition, immediate action can be taken in construction regulations such as to include anticipated climate change impacts in the design regulations and impact studies of coastal defence structures and port developments as well as to determine, as quickly as possible, 
the zones that should be protected and abandoned (with respect to sea level rise) for investment planning.

Adaptation consists of a variety of possible relocation or protection measures, and the key to a coherent management plan is in participation in planning and financing coastal risk prevention at all levels of management (local, regional, and national). Finally, the last recommendation is the adoption of "without regrets" adaptation measures, which address the current coastal risks as a first step toward addressing future coastal risks.

\section{Conclusion}

The estimates presented in this study have a number of imitations due to limited data availability and do not take into account the impacts of current coastal defences or possible adaptations measures. However, the study highlights a number of important points regarding the impacts of climate change. Firstly, this analysis suggests that the cost of current coastal risks is negligible in comparison to the expected costs by 2100 . Secondly, the cost of potential damages due to erosion and permanent inundation are larger than those due to temporary inundation. Thirdly, the cost of improvements currently being implemented on the Lido of Sète (strategic relocation of exposed structures and reinforcement of the lido) give an order of magnitude estimate of necessary adaptation investments.

Despite all of the uncertainties in the quantification of coastal hazard impacts, this study highlights the importance of defining long-term management strategies for the coastal zone, taking into account current risks and predictions of additional future risks due to climate change. At a minimum, it is advisable to reduce short-term coastal risks and to discourage urbanisation and population growth in low-lying, high-risk areas.

\section{References}

Déqué, M., 2003 : «Impacts des changements anthropiques sur la fréquence des phénomènes extrêmes de vent de température et de précipitations (IMFREX). 》 Rapport technique, 3 p., Météo-France/Centre National de Recherches Météorologiques.

Garcin, M., J. F. Desprats, M. Fontaine, R. Pedreros, N. Attanayake, S. Fernando, C. H. E. R. Siriwardana, U. De Silva, and B. Poisson (2008) Integrated approach for coastal hazards and risks in Sri Lanka, Natural Hazards and Earth Systems science. Vol: 8 Issue: 3 p. 577586.

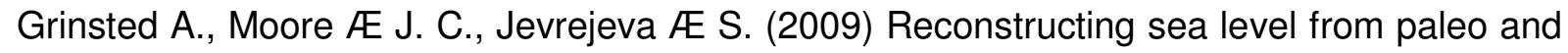
projected temperatures 200 to 2100 AD, Climate Dynamics.

Hallegatte, S., M. Ghil (2008): Natural Disasters Impacting a Macroeconomic Model with Endogenous Dynamics, Ecological Economics, Volume 68, Issues 1-2, 1, Pages 582-592

Hansen J. E. (2007) Scientific reticence and sea level rise, Environmental research letter 2.

IPCC, 2007: Climate Change 2007: Synthesis Report. Contribution of Work Groups I, II, and III to the Fourth Assessment Report, 103p.

Le Cozannet, G. ; Lenôtre N. ,Nacass, P. ; Colas, S. ; Perherin, C., Vanroye C. ; Peinturier C. ; Hajji, C. ; Poupat, B. ; Azzam C. ; Chemitte, J. ; Pons, F., Impacts du Changement Climatique, Adaptation et coûts associés en France pour les Risques Côtiers ; Rapport du Groupe de Travail "Risques Naturels, Assurances et Adaptation au Changement Climatique », BRGM RP 57141, Avril 2009.

McFadden, L., Nicholls R. J., Vafeidis A. T., et al. (2007). A Methodology for Modeling Coastal Space for Global Assessment. Journal of Coastal Research, 23 (4), 911-920. 
Meehl G.A., Stocker T.F., Collins W.D., Friedlingstein P., Gaye A.T., Gregory J.M., Kitoh A., Knutti R., Murphy J.M., Noda A., Raper S.C.B., Watterson I.G., Weaver A.J. And Zhao Z.-C. (2007) - Global Climate Projections. In: Climate Change 2007: The Physical Science Basis. Contribution of Working Group I to the Fourth Assessment Report of the Intergovernmental Panel on Climate Change [Solomon, S.,D. Qin, M. Manning, Z. Chen, M. Marquis, K.B. Averyt, M. Tignor and H.L. Miller (eds.)]. Cambridge University Press, Cambridge, United Kingdom and New York, NY, USA.

Nicholls R. J. (1995) - Synthesis of vulnerability analysis studies. 1993, WORLD Coast'93 . Coastal zone management center . Rijkswaterstaat, The Netherlands. Synthesis of vulnerability analysis studies. , p.1-41.

Nicholls, R.J., Wong P.P., Burkett V.R., Codignotto J.O., Hay J.E., Mclean R.F., Ragoonaden S. And Woodroffe C.D. (2007) - Coastal systems and low-lying areas. Climate Change 2007: Impacts, Adaptation and Vulnerability. Contribution of Working Group II to the Fourth Assessment Report of the Intergovernmental Panel on Climate Change, M.L. Parry, O.F. Canziani, J.P. Palutikof, P.J. van der Linden and C.E. Hansen, Eds., Cambridge University Press, Cambridge, UK, 315-356.

ONERC, 2007. Stratégie nationale d'adaptation au changement climatique. La documentation française, $97 p$.

Paskoff, R., 2000. Implications of accelerated sea-level rise for France. Proceeding of SURVAS Expert workshop on European vulnerability and adaptation to impacts of accelerated se-level rise. Hamburg, Germany, 19th-21st June 2000.

Paskoff, 2001. L'élévation du niveau de la mer et les espaces côtiers, Institut océanographique, ISBN 2-903581-27-4.

Romieu, E. and C. Vinchon, 2009. Evaluation de la vulnérabilité en zone côtière : état de l'art et analyse critique. Rapport final. BRGM/RP-57389-FR. Juillet 2009. 188 pages, 31 figures, 44 tableaux, 4 annexes.

Rahmstorf, S. A., 2007: Semi-empirical approach to projecting future sea-level rise; Science, Vol. 215, pp. 368-369.

Tsimplis, M., M.Marcos, and S. Somot, 2008. 21st century Mediterranean sea level rise: Steric and atmospheric pressure contributions from a regional model, Global and Planetary Change Volume: 63 Issue: 2-3 Pages: 105-111.

Ullmann, A., 2008. Surcotes dans le golfe du Lion et conditions atmosphériques : variabilité contemporaine et future (1905-2100). PhD thesis, Université Aix-Marseille I.

\section{Acknowledgements}

This study was partly funded under the BRGM/MEEDDAT/DGPR/SRNH convention 0001337, action 6.1. For BRGM, the directorate for Research is gratefully acknowledged for support under the Riscote research framework. We thank Dr. S. Hallegatte, E. Romieu, and Dr. Y. Balouin for their useful comments and contributions. 